\title{
Characterization of onion soft rot bacteria in Bangladesh
}

\author{
M. M. Rahman ${ }^{1 *}$, M. A. A. Khan' ${ }^{2}$ I. H. Mian', A. M. Akanda ${ }^{2}$ and M. Z. Alam ${ }^{3}$ \\ ${ }^{I}$ Department of Plant Pathology, Bangladesh Jute Research Institute, Dhaka, Bangladesh \\ ${ }^{2}$ Department of Plant Pathology, Bangabadhu Sheikh Mujibur Rahman Agricultural University, Gazipur, Bangladesh \\ ${ }^{3}$ Department of Entomology, Bangabadhu Sheikh Mujibur Rahman Agricultural University, Gazipur, Bangladesh
}

\begin{abstract}
A study was undertaken for characterization and identification of the soft rot causing bacterial pathogens of onion. Bacterial pathogens were isolated from soft rotted stored onions of different varieties and locations of Bangladesh. Altogether 73 bacterial isolates were isolated from soft rotted onions. Among them, twelve soft rot-positive isolates were selected for characterization and identification on the basis of more virulence. Physiological and biochemical tests were performed following standard methods for characterization and identification of selected soft rot bacterial isolates. Seven isolates namely O-03, O-18, O-69, O-72, O-130, O-156 and O-180 were identified as Pectobacterium carotovorum subsp. carotovorum (E. carotovora subsp. carotovora), two isolates O-101 and O-118 were identified as E. chrysanthemi and three isolates O-05, O-14 and O-15 were the members of Burkholderia cepacia.
\end{abstract}

Keywords : Characterization; Identification; Soft rot bacteria; Onion Bangladesh

\section{Introduction}

Bacterial soft rot commonly occurs in onion after harvest and during storage worldwide. Several bacterial species under different genera can enzymatically macerate parenchymatous tissues of a wide range of plants. Although many bacteria possess the ability to produce tissue macerating enzymes but only a few have been associated with rotting of living plant tissues. These include Erwinia spp., Bacillus subtilis, $B$. polymixa, Pseudomonas marginalis and pectolytic strains of Pseudomonas, Clostridium spp. and Flavibacterium spp. of these, soft rot erwinias are considered to be the most important pathogens of growing plants as well as harvested crops (Perombelon and Kelman, 1980). Toth et al. (2002) reported that the soft rot erwiniae, E. carotovora subsp. carotovora (Ecc), E. carotovora subsp. atroseptica (Eca), and E. chrysanthemi $(E c h)$ are major bacterial pathogens of many crops world-wide. The soft rot of onion is caused by $E$. carotovora subsp. carotovora (Shing, 1985). This organism is a common cause of loss in storage (Sherf and Macnab, 1986). Choi and Han (1990) reported that $P$. marginalis, $P$. syringae and $P$. cepacia caused onion bulb rot in the field and in market places. A similar disease on onion bulbs stored at low temperature condition caused by Burkholderia cepacia was reported by Yi and Park (1999). It was also reported that $P$. fluorescens implicated in soft rot of purple variety of onions in Southern Nigeria by Aboaba (2007). A study confirmed that $P$. marginalis causes soft rot in potato, carrot and onion (Kim et al., 2002). Characterization and Identification of pectolytic erwinias are traditionally based on biochemical and phenotypic characteristics (De Boer and Kelman, 2000) and more recently molecular techniques have also been applied. Several methods have been employed to distinguish pectolytic erwinias. The most commonly used methods are biochemical tests (Dickey and Kelman, 1988) and pathogenicity tests (Smith and Bartz, 1990). A collection of 87 strains of the soft rot pathogen E. carotovora subsp. carotovora (Ecc) isolated from various host plants in Japan, Korea and Thailand was characterized by bacteriological, pathological and genetic properties (Seo et al., 2001). From above discussions it was understood that so many bacterial species/subspecies are involved with soft rot disease of onion. However, little is known about the variability of soft rotted bacterial strains, especially in Bangladesh. In order to improve control measures, detection systems and strategies of breeding for resistance to infection, it is important to improve understanding of their diversity. In Bangladesh research report on soft rot bacteria of onion are very scanty (Rasul et al., 1999; Islam, 2004). Considering the above facts the present study was undertaken for characterization and identification of soft rot bacteria isolated from onion in Bangladesh.

\section{Materials and methods}

Collection of soft rotted diseased samples of onion

Diseased plant samples of onion were selected based on visible symptoms of soft rot and characteristic odor described

\footnotetext{
*Corresponding author e-mail: majibarphdplp@gmail.com
} 
by Rich (1983) and Shing (2001). Symptoms were observed at various levels of post harvested onion bulbs during survey which were presented in Fig. 1. Soft rotted samples of onion were collected from farmers' homes and markets of different locations of Bangladesh. The onion varieties were Kalashnagari, BARI-1, Taherpuri, Faridpuri, Indian varieties and locations were Santhia (Pabna), Sujanagar (Pabna), Gazipur, Rangpur, Karwan Bazar (Dhaka) and Faridpur. After collection of rotted samples brought to the microbiology laboratory of Bangabandhu Sheikh Mujibur Rahman Agricultural University (BSMRAU), Gazipur and the soft rotted bacteria were isolated.

\section{Isolation of soft rot bacteria}

Soft rot bacterial isolates were isolated from different sample of onion by "Streak plate" technique as described by

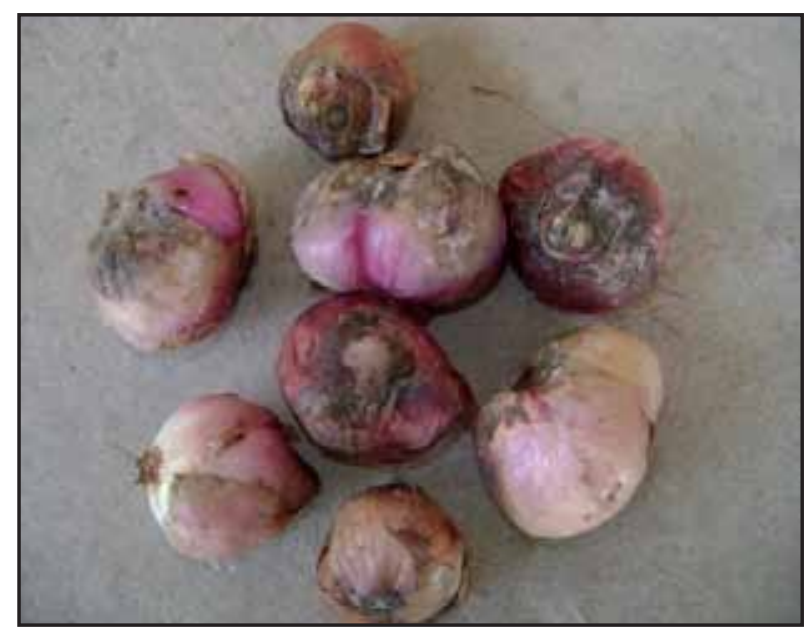

A. Soft rotted Onion collected from farmers home during survey

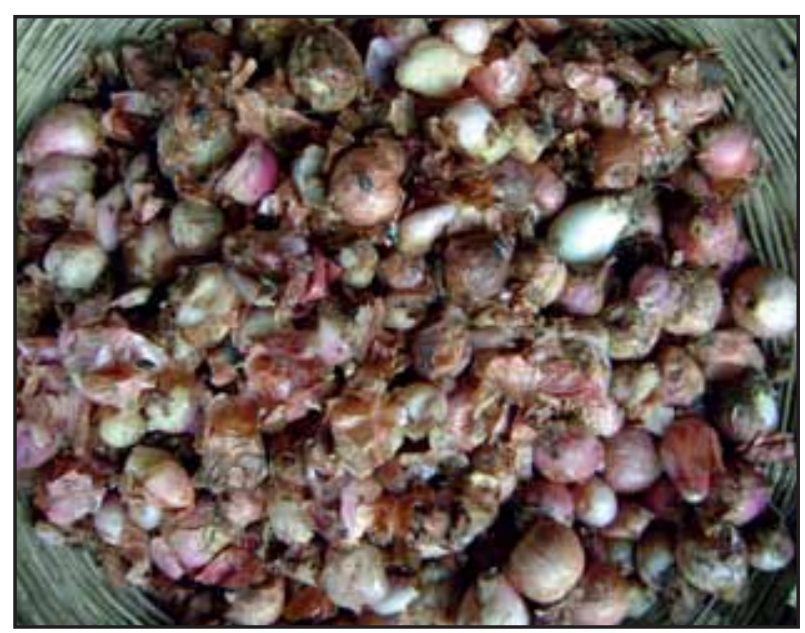

C. Soft rotted onion collected from market during survey
Mortensen (1997) and Kim et al. (2002). A common bacteriological medium, yeast peptone dextrose agar (YPDA) was used for isolation of soft rot bacteria. YPDA was prepared by dissolving yeast $3.0 \mathrm{~g}$, peptone $0.6 \mathrm{~g}$, dextrose $3.0 \mathrm{~g}$, and agar $15 \mathrm{~g}$ in $1000 \mathrm{ml}$ of distilled water. The $\mathrm{pH}$ of the medium was adjusted to 7.0 using $0.1 \mathrm{~N} \mathrm{KOH}$ and cooked on hot plate. After cooking the medium was autoclaved for $20 \mathrm{~min}$ at $121^{\circ} \mathrm{C}$ under $1.1 \mathrm{~kg} / \mathrm{cm}^{2}$ pressures. The medium was poured into petridishes at the rate of $20 \mathrm{ml} /$ plate and were cooled in a clean bench. To isolate the causal bacteria, small part from the margin of rotted tissues of the infected bulbs of onion samples were separated with a scalpel and were surface disinfected with $1 \%$ sodium hypochlorite $(\mathrm{NaOCl})$ for 2-3 min. Sterilized samples were washed several times in sterilized water to remove the residual hypochlorite. The samples were placed in petridishes containing sterilized

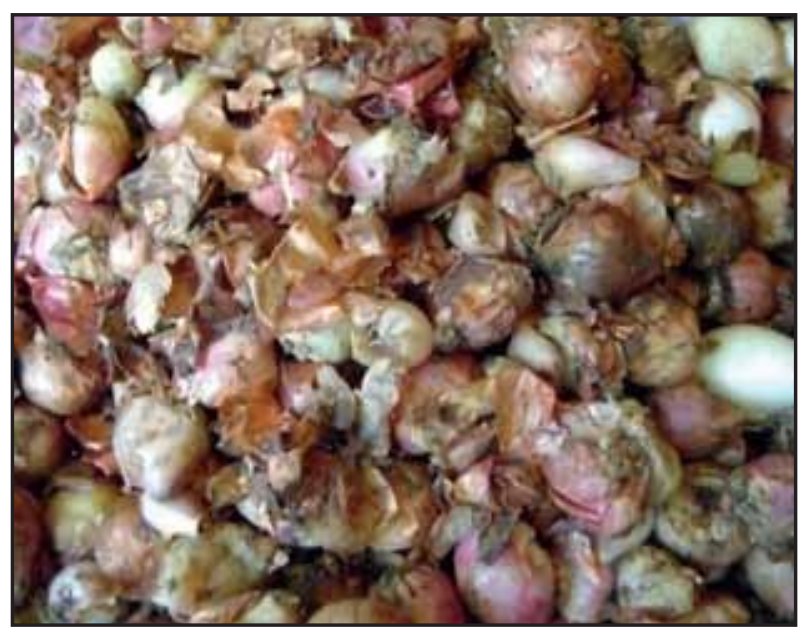

B. Soft rotted onion collected from market during survey

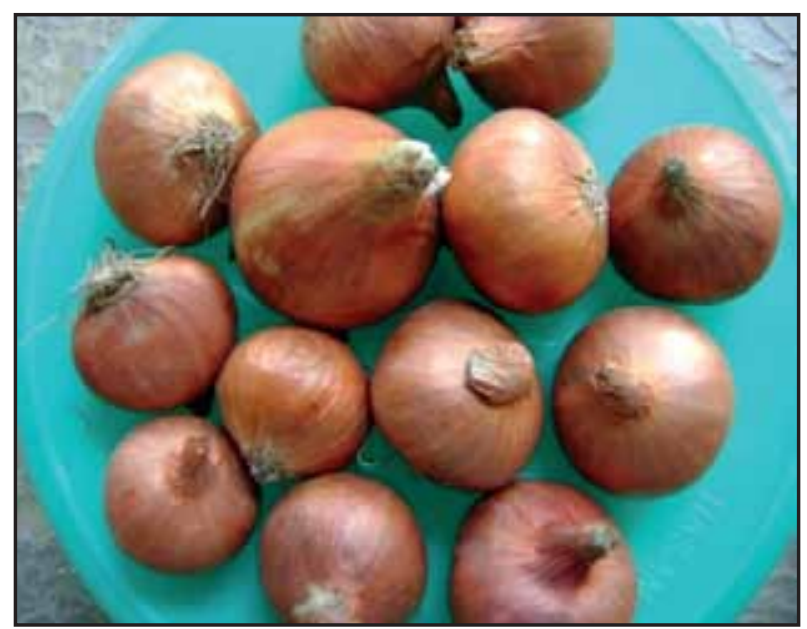

D. Fresh onion collected during survey

Fig. 1. Soft rotted symptoms (A-C) and fresh onion (D) collected from different post harvest levels 
water and were crushed with a sterile scalpel. After crushing, the petridishes were kept undisturbed for 10-15 $\mathrm{min}$ to release the bacteria associated with rotted tissues. One loop full of resulting suspension (water containing bacteria) was streaked on the solidified YPDA medium in each plate. The plates were incubated at $30^{\circ} \mathrm{C}$ for $48 \mathrm{hr}$. Characteristic individual bacterial colonies that appeared on YPDA medium were picked up using a bacterial loop and transferred to another plate. Purification of bacterial colony was done by re-streaking of single colony on another fresh plate.

\section{Potato and onion soft rot test}

All of the bacterial isolates originated from single colonies were tested for their ability to cause soft rot on potato tubers and onion bulbs following standard procedure (Lelliot et al., 1966). Potato tubers and onion bulbs were sterilized with $70 \%$ ethyl alcohol, rinsed in sterile distilled water and aseptically cut into slices (ca. 1 $\mathrm{cm})$. The slices were put in petridishes containing sterilized filter paper impregnated with ca. $2 \mathrm{ml}$ of sterilized distilled water. The soft rot tests were repeated at least twice for fulfilling the Koch's postulates. The slices were inoculated with needle pricking method. The inoculated slices were maintained in moistened petridishes (Togashi, 1988; Nabhan et al., 2006) and incubated at $30^{\circ} \mathrm{C}$ for 2-3 days. The bacterial cultures produced characteristic symptoms of soft rot on potato and onion slices were selected and preserved more virulence isolates for further studies.

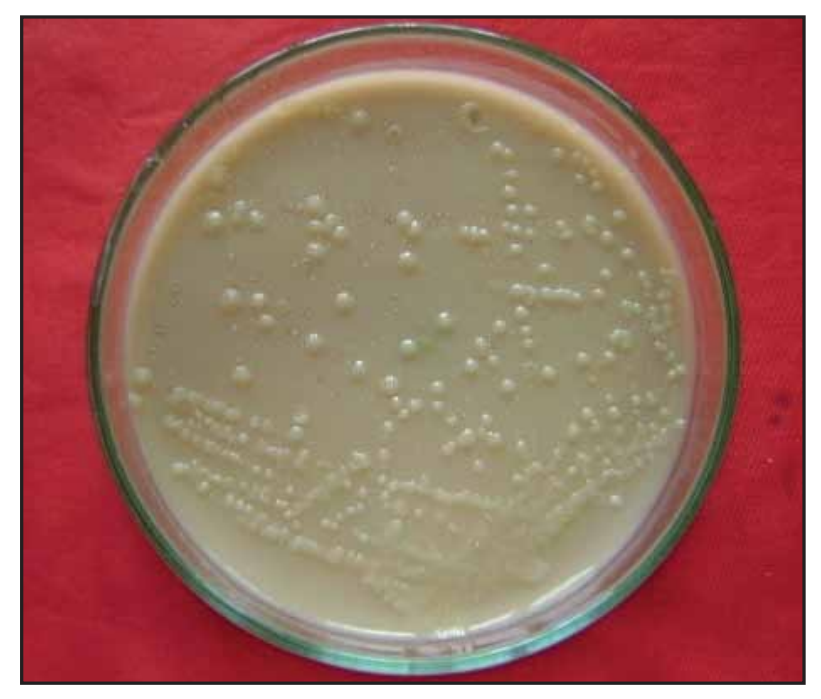

A. Grayish white and raised colonies on YPDA

\section{Preservation of pathogenic bacterial strains}

Pure single colonies of each of pathogenic soft rot bacterial isolates of onion were preserved in test tubes containing sterilized distilled water and in test tube with half slant culture containing YPDA overlapped with sterilized liquid paraffin. The tubes containing culture were preserved in a cool room $\left(14^{0} \mathrm{C}\right)$.

\section{Characterization of the pathogenic bacterial strains}

A series of physiological and biochemical tests were performed for characterization of the isolated more pathogenic isolates. The physiological and biochemical tests were a. Potato soft rot test b. Fermentation of glucose (OF test) (Hugh and Leifson, 1953), c. Gram reaction (Suslow et al., 1982), d. Oxidase reaction (Kovacs, 1956), e. Catalase production (Hayward, 1992), f. Gelatin Liquefaction test (Schaad, 1988), g. Urease production (Schaad, 1988), h. Nitrate reduction test (Lelliott and Dickey, 1984), i. Indol test (Lelliott and Dickey, 1984), j. Lecithinase test (Clung and Tobae, 1947), k. Acetoin production (Dye, 1969), 1. Methyl red test, m. Arginine dihydrolase (Thornley, 1960), n. Gas formation (Hugh and Leifson, 1953), o. Hypersensitive reaction (Klement and Goodman, 1967) and p. Utilization of carbon (Ayers et al., 1919).

Three soft rotting bacterial strains Erwinia carotovora subsp. carotovora ATCC-15713, E. chrysanthemi Ura-2 and Burkholderia cepacia ATCC 25416 were used as reference strains in this experiment.

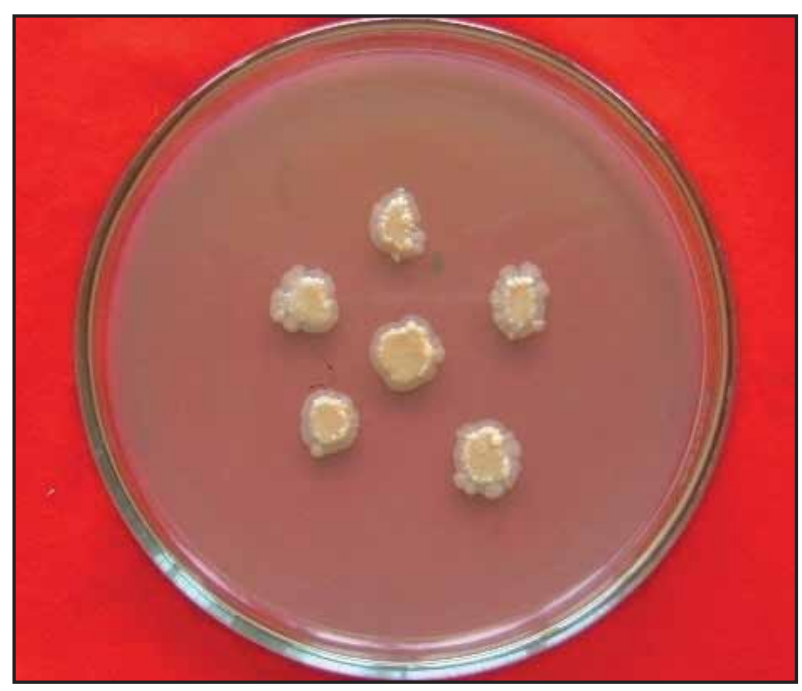

B. Creamy white and margins undulated to feathery colonies on YPDA

Fig. 2. Various types of bacterial colonies isolated from soft rotted onion (A-B) 


\section{Results and discussion}

Collection and isolation of soft rot bacterial isolates

A total of 73 isolates from onion were isolated from different locations of Bangladesh (list not included). Colony morphology of most of the isolates on YPDA were white, creamy white, and grayish creamy white, smooth, round, glistening, slightly raised and some were flat to slightly raised, margins undulated to feathery and visible on isolation plates after about $24 \mathrm{~h}$ (Fig. 2, A-B).

\section{Potato and onion soft rot test}

Based on the results of soft rot test on onion and potato, the pathogenic isolates were selected from the isolated 73 isolates. 24 isolates produced soft rot on onion and potato slices among 73 isolates (Table-I and Fig. 3, A-B). All of the pathogenic isolates were preserved in test tube overlapping with liquid paraffin for further study. Twelve (12) soft rot-positive isolates were selected (on the basis of more virulence) for characterization and identification. More virulence isolates (12 isolates) were selected on the basis of aggressiveness and more soft rotted area produced on host samples.

Table I. List of potato soft rot positive isolates isolated from different soft rotted onion varieties and locations of Bangladesh

\begin{tabular}{|c|c|c|c|c|c|}
\hline Sl. No. & Isolate no. & Colony characters & Locations & Potato soft rot test & Isolation time \\
\hline 1 & O-03 & Creamy white small & Santhia & + & 2008 \\
\hline 2 & O-05 & Creamy white & , & + & , \\
\hline 3 & O-14 & Creamy white & Rangpur & + & , \\
\hline 4 & O-15 & , & Dhaka & + & , \\
\hline 5 & O- 18 & Grayish white & , & + & , \\
\hline 6 & $\mathrm{O}-42$ & Creamy white & Sujanagar & + & 2009 \\
\hline 7 & O-52 & White sticky & Sujanagar & + & $"$ \\
\hline 8 & O-62 & Creamy white & Gazipur & + & , \\
\hline 9 & O-69 & White sticky & , & + & , \\
\hline 10 & O-72 & Creamy white & Sujanagar & + & , \\
\hline 11 & O-73 & White small & , & + & , \\
\hline 12 & O-75 & Creamy white small & , & + & \\
\hline 13 & O-76 & $"$ & , & + & $"$ \\
\hline 14 & O-77 & Creamy white & , & + & , \\
\hline 15 & O-78 & White small &, & + & $"$ \\
\hline 16 & O- 80 & Creamy white small & Santhia & + & $"$ \\
\hline 17 & O-101 & White sticky & , & + & $"$ \\
\hline 18 & O-118 & Grayish white & Gazipur & + & , \\
\hline 19 & $\mathrm{O}-120$ & Creamy white small & Santhia & + & , \\
\hline 20 & O-121 & $"$ & $"$ & + & $"$ \\
\hline 21 & O-129 & Creamy white & , & + & , \\
\hline 22 & O-130 & Creamy white small &, & + & $"$ \\
\hline 23 & O-156 & Creamy white small & Rangpur & + & , \\
\hline 24 & O-180 & Grayish creamy white & Gazipur & + & 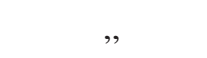 \\
\hline
\end{tabular}




\section{Characterization of onion isolates}

\section{Physiological and biochemical tests}

All the twelve bacterial isolates (O-03, O-05, O-14, O-15, O-18, O-69, O-72, O-101, O-118, O-130, O-156 and O-180) and two reference strains E. carotovora subsp. carotovora ATCC 15713 and E. chrysanthemi Ura-2 were found positive in potato soft rot, catalase (Fig. 4), oxidative, gelatin liquefaction, acetoin test, growth at $37^{\circ} \mathrm{C}$ and tobacco hypersensitivity tests (Fig. 9) but negative in gram reaction, oxidase test and arginine utilization tests and they differed in OF test, nitrate reduction, lecithinase test, methyl red test,

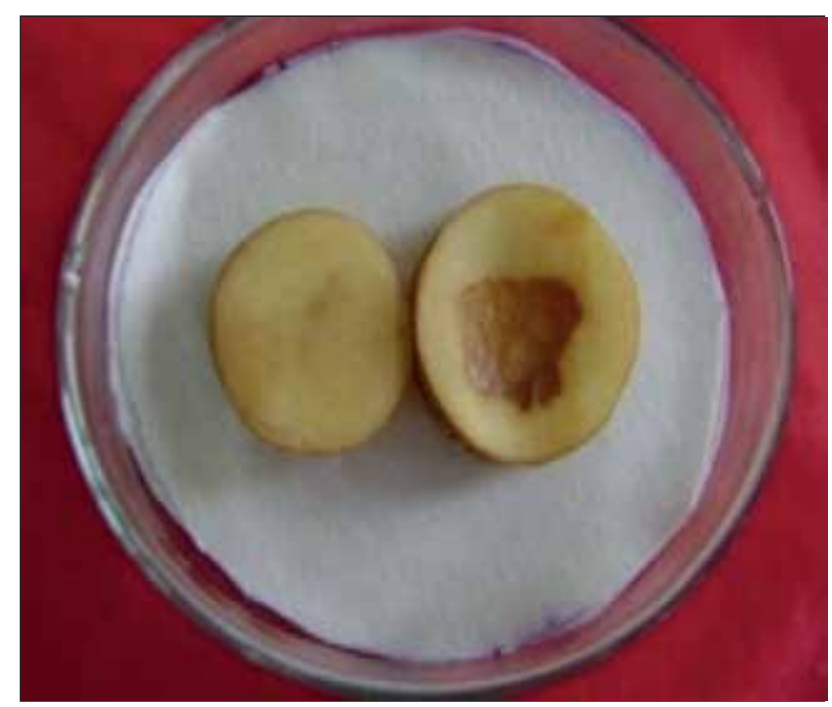

A. Soft rot positive (right, $\mathrm{O}-15$ ), negative (left) indole test, in gas formaton and growth in $5 \% \mathrm{NaCl}$ (Table II).

Nine isolates (O-03, O-18, O-69, O-72, O-101, O-118, O-130, O-156 and O-180) and two reference strains $E$. carotovora subsp. carotovora ATCC 15713 and E. chrysanthemi Ura-2 gave positive results in the OF test i.e., they produce yellow color in both liquid paraffin covered and uncovered tubes (Table II and Fig. 5). So these isolates belong to facultative anaerobic bacteria. Three isolates such as O-05, O-14, O-15 and a reference strains B. cepacia ATCC 25416 gave negative results in this test. So these isolates did not ferment glucose in covered tubes. i.e., these bacteria were strictly aerobic.

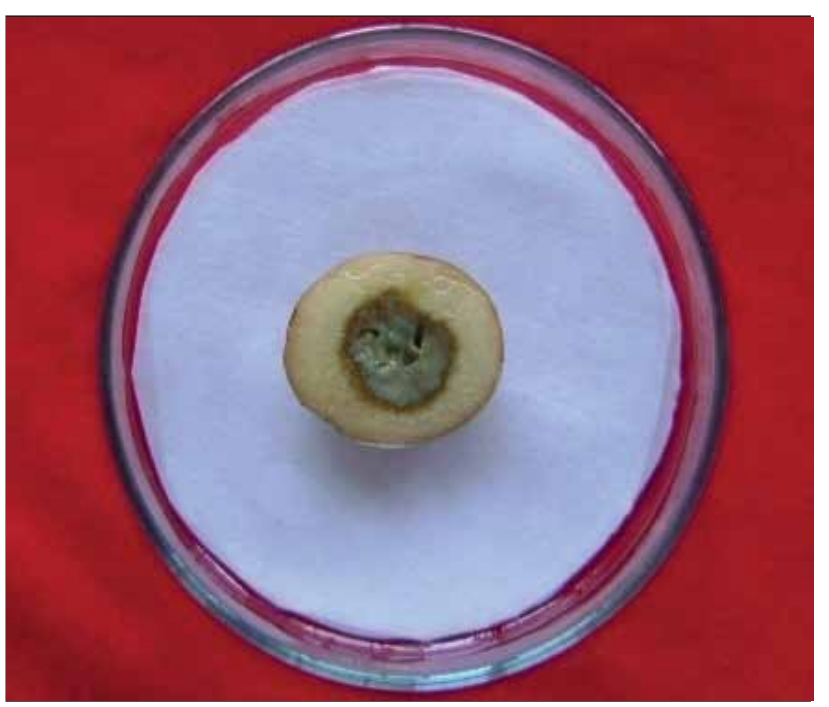

B. Soft rot positive $(\mathrm{O}-118)$

Fig. 3. Soft rot test on potato slices of different soft rot bacterial strains (A-B)

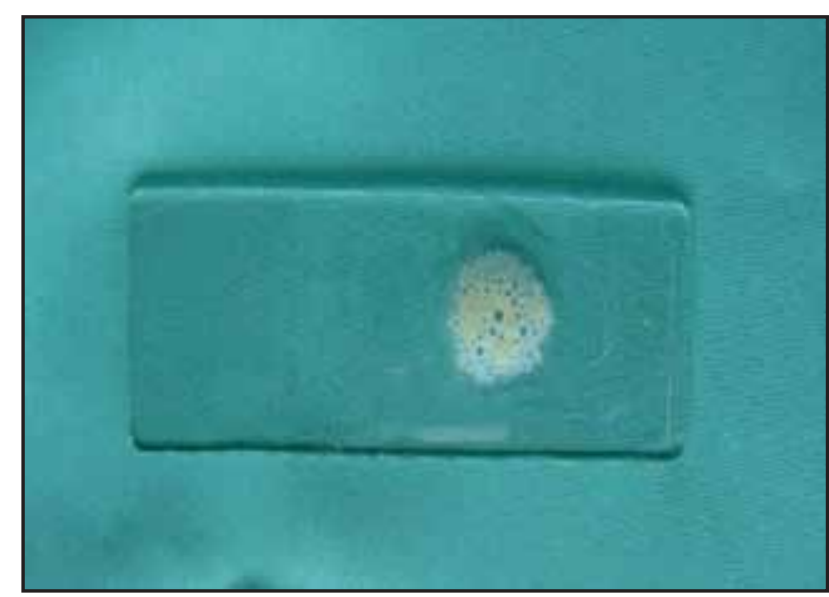

A

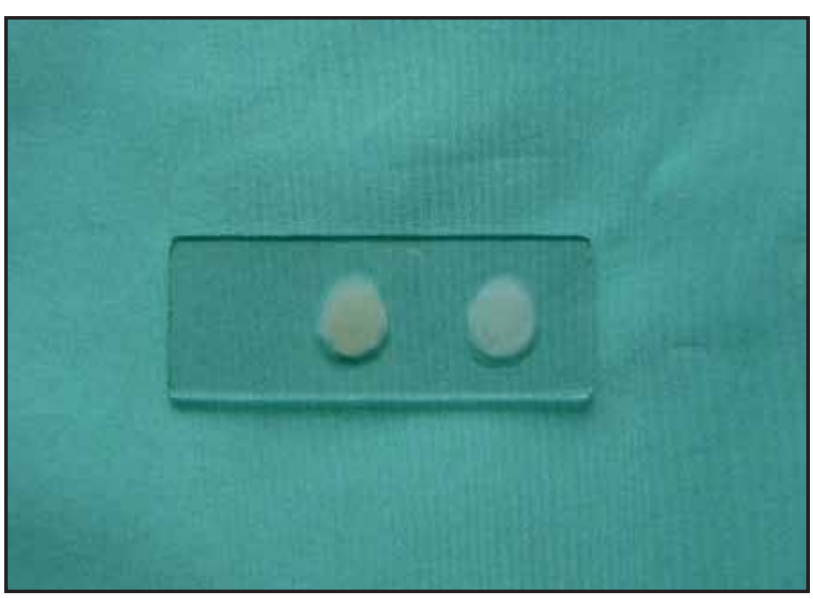

B

Fig. 4. Catalase test of soft rot bacteria, positive-showing gas bubble (A), negative-not showing gas bubble (B) 


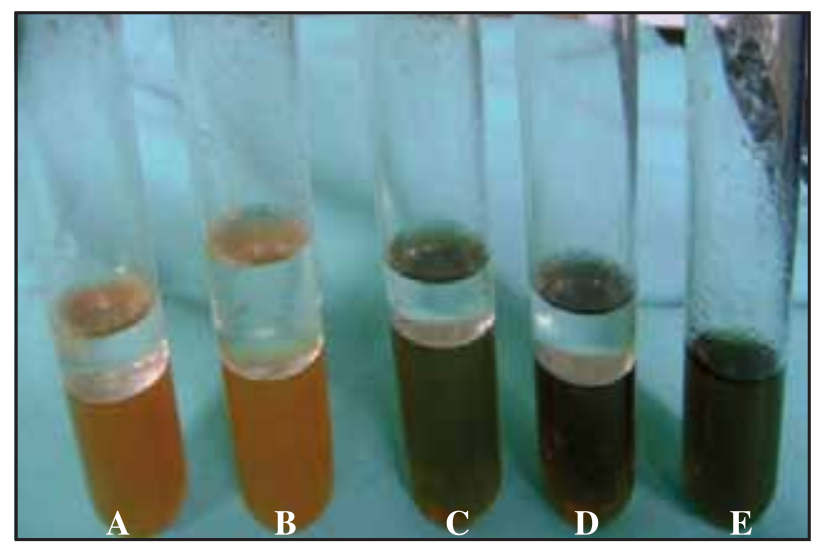

Fig. 5. Oxidative and fermentative test: A, B positive reaction; $\mathrm{C}$, D-negative reaction; $\mathbf{E}$-control (no glucose added)

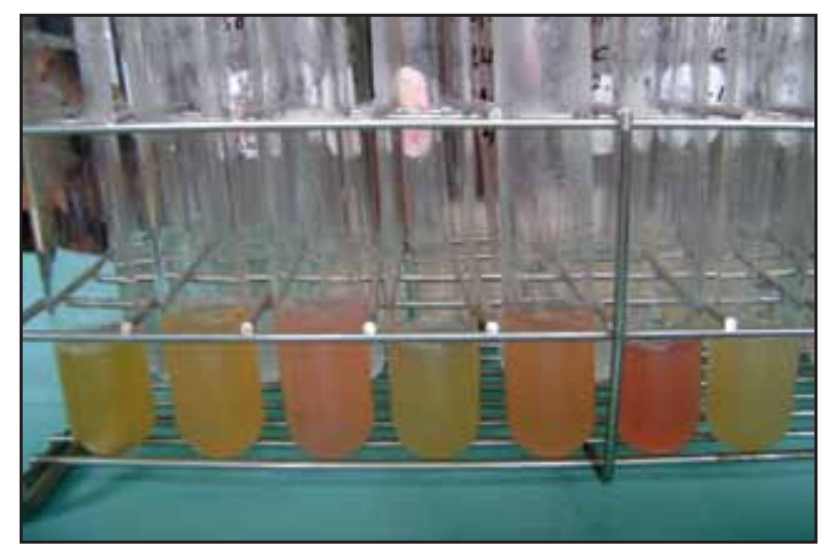

Fig. 7. Methyl red test of soft rot bacteria: red color - positive reaction

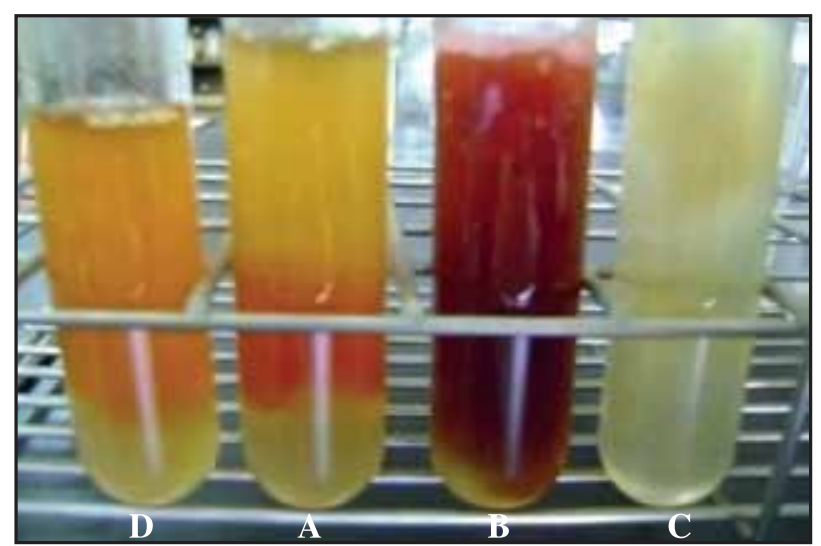

Fig. 6. Nitrate reduction test: A-weakly positive; B-strongly positive; C-negative; D-variable reaction/very weakly positive

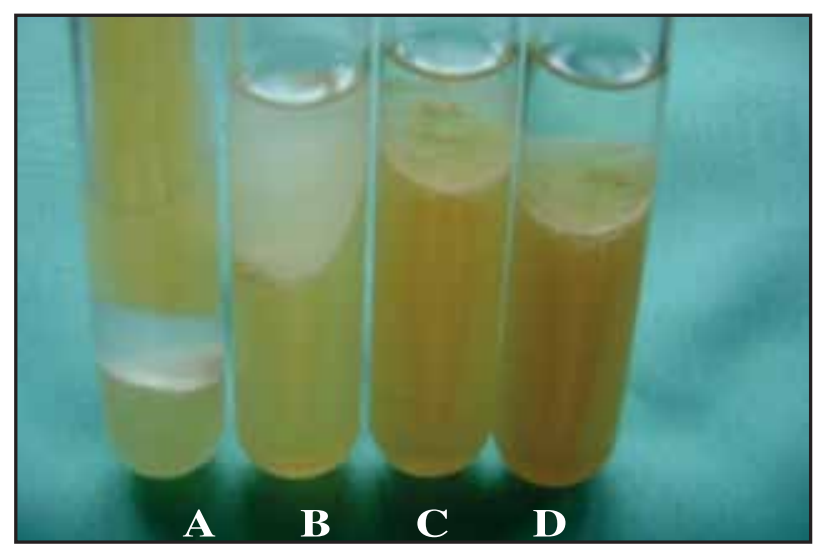

Fig. 8. Gas formation test: A-positive, formation of bubbles/vacuum in the medium and the petrolatum seal being pushed upward; B, C, D-negative

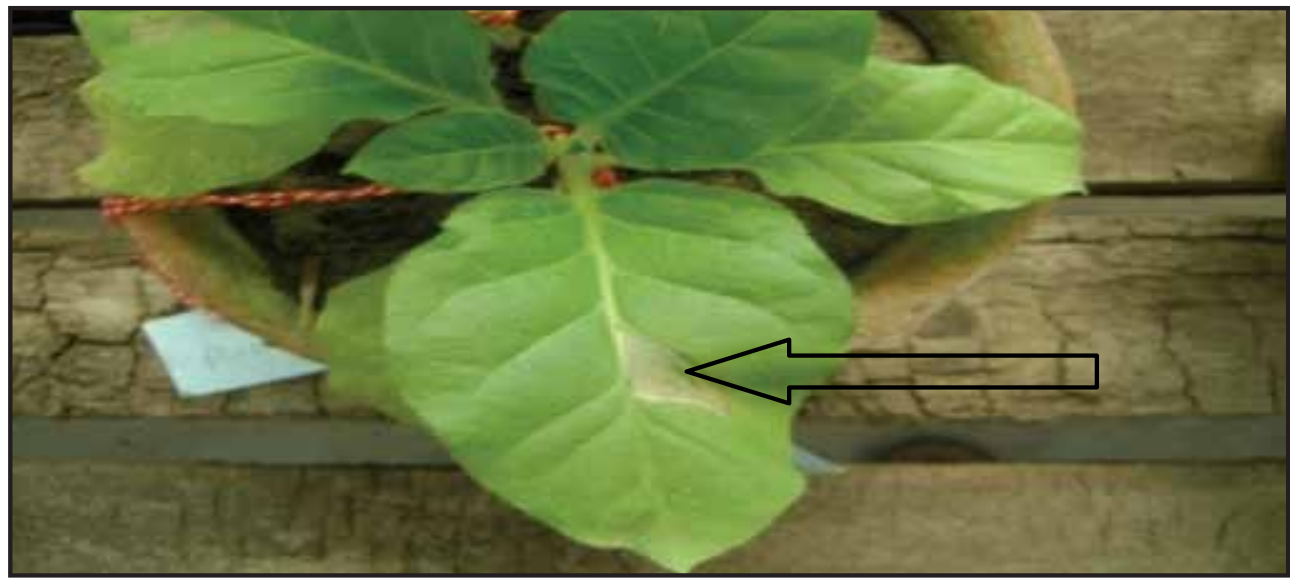

Fig. 9. Tobacco hypersensitivity test: A-positive, the tissues became collapsed within $24 \mathrm{~h}$ after inoculation and necrotic and the bacteria are trapped and die; B-negative 
In case of nitrate reduction test, nine isolates $(\mathrm{O}-03, \mathrm{O}-18$, O-69, O-72, O-101, O-118, O-130, O-156 and O-180) and two reference strains $E$. carotovora subsp. carotovora ATCC 15713 and $E$. chrysanthemi Ura-2 were positive. But three isolates (O-05, O-14 and O-15) and a reference strains $B$. cepacia ATCC 25416 were negative in this test (Table II and Fig. 6).

Among the 12 virulence isolates, seven isolates $(\mathrm{O}-03, \mathrm{O}-18$, O-69, O-72, O-130, O-156 and O-180) and two reference strains E. carotovora subsp. carotovora ATCC 15713 and $E$. chrysanthemi Ura-2 were negative in the lecithinase test and three isolates (O-14, O-101 and O-118) and a reference strains $E$. chrysanthemi Ura-2 were positive and two isolates (O-05 and O-15) gave variable reaction in this test.

In case of methyl red test, 10 isolates (O-03, O-05, O-14, O-15, O-18, O-69, O-72, O-130, O-156 and O-180) and two reference strain $E$. carotovora subsp. carotovora ATCC 15713 and B. cepacia ATCC 25416 gave positive result while the two isolates $(\mathrm{O}-101, \mathrm{O}-118)$ and a reference strains E. chrysanthemi Ura-2 gave negative results in this test (Table II and Fig. 7).

Table II. Physiological and biochemical characteristics of soft rot bacteria isolated from onion

\begin{tabular}{|c|c|c|c|c|c|c|c|c|c|}
\hline \multirow{2}{*}{ Isolates No. } & \multicolumn{8}{|c|}{ Name of Tests } & \multirow[b]{2}{*}{ 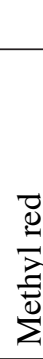 } \\
\hline & 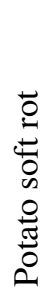 & 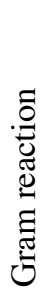 & $\frac{\mathbb{E}}{\frac{\tilde{J}}{\tilde{J}}}$ & 岕 & 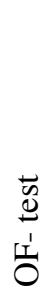 & 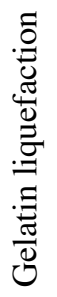 & 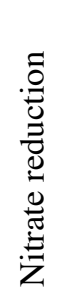 & 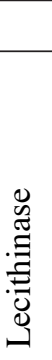 & \\
\hline O-03 & + & - & + & - & + & + & + & - & + \\
\hline $\mathrm{O}-05$ & + & - & + & - & - & + & - & $\mathrm{v}$ & + \\
\hline O-14 & + & - & + & - & - & + & - & + & + \\
\hline O-15 & + & - & + & - & - & + & - & $\mathrm{v}$ & + \\
\hline O-18 & + & - & + & - & + & + & + & - & + \\
\hline O-69 & + & - & + & - & + & + & + & - & + \\
\hline $\mathrm{O}-72$ & + & - & + & - & + & + & + & - & + \\
\hline O-101 & + & - & + & - & + & + & + & + & - \\
\hline O-118 & + & - & + & - & + & + & + & + & - \\
\hline O-130 & + & - & + & - & + & + & + & - & + \\
\hline O-156 & + & - & + & - & + & + & + & - & + \\
\hline O-180 & + & - & + & - & + & + & + & - & + \\
\hline Ecc ATCC 15713 & + & - & + & - & + & + & + & - & + \\
\hline Ech Ura-2 & + & - & + & - & + & + & + & + & - \\
\hline Bc ATCC 25416 & + & - & + & - & - & + & - & - & + \\
\hline
\end{tabular}


Table II. Physiological and biochemical characteristics of soft rot bacteria isolated from onion (continued)

\begin{tabular}{|c|c|c|c|c|c|c|c|}
\hline \multirow{2}{*}{ Isolates No. } & \multicolumn{6}{|c|}{ Name of Tests } & \multirow[b]{2}{*}{$\begin{array}{c}\text { Tobacco } \\
\text { hypersensitivity }\end{array}$} \\
\hline & $\begin{array}{l}\text { Arginine } \\
\text { utilization }\end{array}$ & Acetoin & Indole & $\begin{array}{c}\text { Gas } \\
\text { formation }\end{array}$ & $\begin{array}{c}\text { Growth at } \\
37^{\circ} \mathrm{C}\end{array}$ & $\begin{array}{l}\text { Growth in } \\
5 \% \mathrm{NaCl}\end{array}$ & \\
\hline-03 & - & + & - & - & + & + & + \\
\hline $\mathrm{O}-05$ & - & + & $\mathrm{v}$ & - & + & - & + \\
\hline O-14 & - & + & $\mathrm{v}$ & - & + & - & $\mathrm{w}+$ \\
\hline O-15 & - & + & $\mathrm{v}$ & - & + & - & + \\
\hline O-18 & - & + & - & - & + & + & + \\
\hline $0-69$ & - & $\mathrm{w}+$ & - & - & + & + & + \\
\hline O-72 & - & + & - & - & + & + & + \\
\hline O-101 & - & + & + & + & + & - & $\mathrm{w}+$ \\
\hline O-118 & - & + & + & + & + & - & + \\
\hline $\mathrm{O}-130$ & - & + & - & - & + & + & + \\
\hline O-156 & - & + & - & - & + & + & + \\
\hline O-180 & - & + & - & - & + & + & + \\
\hline Ecc ATCC 15713 & - & + & - & - & + & + & + \\
\hline Ech Ura-2 & - & + & + & + & + & - & + \\
\hline Bc ATCC 25416 & - & + & $\mathrm{v}$ & - & $\mathrm{w}+$ & - & $\mathrm{W}+$ \\
\hline
\end{tabular}

Reference/standard isolates: Ecc ATCC 15713 (Ecc=E. carotovora subsp. carotovora), Ech Ura-2 (Ech= E. chrysanthemi), Bc ATCC $25416(\mathrm{Bc}=\mathrm{B}$. cepacia $)$, ATCC $=$ American Type Culture Collection; $(+)=$ growth positive $;(-)=$ negative; $($ w +$)=$ weakly positive; $(\mathrm{v})=$ variable reaction

In the indole test, seven isolates (O-03, O-18, O-69, O-72, O-130, O-156 and O-180) and a reference strain $E$. carotovora subsp. carotovora ATCC 15713 were negative while two isolates (O-101 and O-118) ) and E. chrysanthemi Ura-2 were found positive. The remaining three isolates (O-05, O-14 and O-15) and the reference isolate B. cepacia ATCC 25416 showed variable reaction (Table II).

Two isolates (O-101 and O-118) and a reference strain $E$. chrysanthemi Ura-2 were positive in gas formation. The other 10 isolates and two reference strains $E$. carotovora subsp. carotovora ATCC 15713 and B. cepacia ATCC 25416 did not produce any gas bubbles in the test (Table II and Fig. 8).

The results of physiological and biochemical tests and carbon sources utilization tests also revealed that three isolates of onion O-05, O-14 and O-15 were identical with reference strain of Burkholderia cepacia ATCC 25416 and they were identified as B. cepacia (Table III, IV and V). Similar type 
Table III. Utilization of different sugars as source of carbon by soft rot bacterial isolates of onion

\begin{tabular}{|c|c|c|c|c|c|c|c|c|c|}
\hline \multirow{2}{*}{ Isolates No. } & \multicolumn{8}{|c|}{ Name of carbon sources } & \multirow[b]{2}{*}{ Trehalose } \\
\hline & Cellubiose & Lactose & Maltose & Maltose & D-Galactose & D-Xylose & Raffinose & Sucrose & \\
\hline $\mathrm{O}-03$ & + & + & - & + & + & + & + & + & + \\
\hline $\mathrm{O}-05$ & + & - & - & + & + & + & + & + & + \\
\hline $\mathrm{O}-14$ & + & - & - & + & + & + & + & + & + \\
\hline $\mathrm{O}-15$ & + & - & - & + & + & + & + & + & + \\
\hline O-18 & + & + & - & + & + & + & + & + & + \\
\hline O-69 & + & + & - & + & + & + & + & + & + \\
\hline $\mathrm{O}-72$ & + & + & - & + & + & + & + & + & + \\
\hline O-101 & + & - & - & + & + & + & + & + & - \\
\hline O-118 & + & - & - & + & + & + & + & + & - \\
\hline O-130 & + & + & - & + & + & + & + & + & + \\
\hline O-156 & + & + & - & + & + & + & + & + & + \\
\hline O-180 & + & + & - & + & + & + & + & + & + \\
\hline Ecc ATCC 15713 & + & + & - & + & + & + & + & + & + \\
\hline Ech Ura-2 & + & - & - & + & + & + & + & + & - \\
\hline Bc ATCC 25416 & + & - & - & + & + & + & + & + & + \\
\hline
\end{tabular}

Reference/standard isolates: Ecc ATCC 15713 (Ecc=E. carotovora subsp. carotovora), Ech Ura-2 (Ech= E. chrysanthemi), Bc ATCC 25416 (Bc=B . cepacia), ATCC= American Type Culture Collection; + = growth positive; - = negative; $v=$ variable reaction

results of physiological, biochemical and carbon source utilization for B. cepacia were reported earlier (Kreig and Holt, 1984; Schaad, 1988; Alam et al., 1999; Khan, 2000).

Three soft rot bacteria such as Pectobacterium carotovorum subsp. carotovorum (E. carotovora subsp. carotovora), E. chrysanthemi and Burkholderia cepacia were identified as causative agents of onion soft rot disease in Bangladesh at the present study. Characterization and Identification of pectolytic erwinias are traditionally based on biochemical and phenotypic characteristics and more recently molecular techniques have also been applied by De Boer and Kelman (2000). Several methods have been employed to distinguish among pectolytic erwinias. The most commonly used methods are biochemical tests (Dickey and Kelman, 1988) and pathogenicity tests (Smith and Bartz, 1990). In the present study, characterization and identification of soft rot bacteria of onion were mostly based on the traditional methods. In Bangladesh, molecular based techniques yet not been performed for characterization and identification of soft 
Table IV. Utilization of different alcohols and organic acids by soft rot bacterial isolates of onion

\begin{tabular}{|c|c|c|c|c|c|c|}
\hline \multirow{2}{*}{ Isolates No. } & \multicolumn{6}{|c|}{ Name of alcohols and organic acids } \\
\hline & Dulcitol & Inositol & Manitol & Sorbitol & Benzoate & D-Tartrate \\
\hline $\mathrm{O}-03$ & - & + & + & - & - & - \\
\hline $\mathrm{O}-05$ & - & + & + & - & - & - \\
\hline O-14 & - & + & + & - & - & - \\
\hline O-15 & - & + & + & - & - & - \\
\hline O-18 & - & + & + & - & - & - \\
\hline O-69 & - & + & + & - & - & - \\
\hline O-72 & - & + & + & - & - & - \\
\hline O-101 & - & - & + & - & - & - \\
\hline O-118 & - & - & + & - & - & - \\
\hline O-130 & - & + & + & - & - & - \\
\hline O-156 & - & + & + & - & - & - \\
\hline O-180 & - & + & + & - & - & - \\
\hline Ecc ATCC 15713 & - & + & + & - & - & - \\
\hline Ech Ura-2 & - & - & + & - & - & - \\
\hline Bc ATCC 25416 & - & + & + & - & - & - \\
\hline
\end{tabular}

Reference/standard isolates: Ecc ATCC 15713 (Ecc=E. carotovora subsp. carotovora), Ech Ura-2 (Ech= E. chrysanthemi), Bc ATCC 25416 (Bc=B. cepacia), ATCC= American Type Culture Collection; + = growth positive; - = negative

Table V. List of identified soft rot bacterial isolates of onion from different locations of Bangladesh according to growth, physiological and biochemical characteristics

\begin{tabular}{lccc}
\hline Sl. No. & No. of Isolates & Locations & Identified as \\
\hline 1 & O-03 & Santhia, Pabna & Erwinia carotovora subsp. carotovora \\
2 & O-05 & Rangpur & Berkholderia cepacia \\
3 & O-14 & Dhaka & B. cepacia \\
4 & O-15 & B. cepacia \\
5 & O-18 & Sujanagar, Pabna & E. carotovora subsp. carotovora \\
6 & O-69 & , & E. carotovora subsp. carotovora \\
7 & O-72 & Gazipur & E. carotovora subsp. carotovora \\
8 & O-101 & Karwan Bazar & E. chrysanthemi \\
9 & O-118 & O-130 & E. chrysanthemi \\
10 & O-156 & Rangpur & E. carotovora subsp. carotovora \\
11 & O-180 & Gazipur & E. carotovora subsp. carotovora \\
12 & & E. carotovora subsp. carotovora \\
\hline
\end{tabular}


rot bacteria of onion due to lack of facilities. That's why molecular based techniques should be included in future for characterization and identification of soft rot bacterial strains of onion in Bangladesh.

\section{Conclusion}

Among the 12 selected virulent isolates, Pectobacterium carotovorum subsp. carotovorum (E. carotovora subsp. carotovora) was the major soft rot pathogen of onion in Bangladesh. These findings were based on traditional biochemical and physiological analysis, however, molecular analysis (De Boer and Kelman, 2000) is more reliable than the conventional biochemical and physiological analysis to draw a strong conclusion. Future work plan is suggested using molecular based techniques.

\section{Acknowledgement}

The authors are grateful to Ministry of Science and Information \& Communication Technology, Bangladesh, for assistance by providing (NSICT) fellowship to conduct the study.

\section{References}

Aboaba OO (2007), Growth studies of Pseudomonas fluorescens implicated in soft rot of purple variety of onions in southern Nigeria, Nature and Sci. 5(4): 75-80.

Alam SMK, Tigashi J, Ohtomo T and Namai T (1999), Bacterial soft rot, a new disease of Pak-Choi (Brassica campestris L. chinensis group) caused by Erwinia carotovora, Ann. Phytopathol. Soc. Jpn. 65(1): 46-48.

Ayers SH, Rupp P and Johnson WT (1919), A study of the alkali forming bacteria in milk, U. S. Dept. Agric. Bull, p 782 .

Choi JE and Han KS (1990), Studies on the bacterial soft rot disease of lilliaceae crops in Korea, Korean J. Plant Pathol 6: 358-362.

Clung Mc L S and Tobe R (1947), The egg yolk plate reaction for the presumptive diagnosis of clostridium sorogenes and certain species of the gangrene and botulinum groups, J. Bacteriol 53: 139-147.

De Boer SH and Kelman A (2000), Gram-negative bacteria: Erwinia soft rot group In: Laboratory Guide for Identification of Plant Pathogenic Bacteria, Eds. Schaad NW, Jones JB and Chun W, $3^{\text {rd }}$ Ed., pp 56-72.
Dickey RS and Kelman A (1988), Erwinia carotovora or soft rot group In: Schaad NW Laboratory Guide for Identification of Plant Pathogenic Bacteria, $2^{\text {nd }}$ Ed., St Paul. MN, American Phytopathological Society, p 4459.

Dye DN (1969), A taxonomic study of the genus Erwinia. 1. The amylovora group, New Zealand J. Sci. 11: 590-607.

Hayward AC (1992), Identification of Pseudomonas solanacearum. In: SAVERNET Bacterial Wilt Training Course held on October 5 to November 16 AVRDC, $p$ 101.

Hugh R and Leifson E (1953), The taxonomic significance of fermentative versus oxidative metabolism of carbohydrates by various gram-negative bacteria, $J$. Bacteriol 66: 24-26.

Islam AKMS (2004), Characterization of soft rot bacterial pathogen of some vegetables, M.Sc. Thesis, Dept. of Plant Pathology, Bangabandhu Sheikh Mujibur Rahman Agricultural University, Gazipur, Bangladesh, p 69.

Khan AA (2000), Studies on rapid identification of phytopathogenic bactria, $P h D$. Thesis, Laboratory of Plant Pathology, Faculty of Agriculture, Kyushu University, Fukuoka, Japan, p 131.

Kim YK, Lee SD, Choi CS, Lee SB and Lee SY (2002), Soft Rot of Onion Bulbs Caused by Pseudomonas marginalis Under Low Temperature Storage, The Korean Society of Plant Pathology, Plant Pathol. J. 18(4): 199-203.

Klement A and Goodman R (1967), The hypersensitive reaction to infection by bacterial plant pathogens, Ann. Rev. Phytopathol 5: 17-44.

Kovacs N (1956), Identification of Pseudomonas solanacearum by the oxidase reaction, Nature, 178: 703.

Kreig NR and Holt JG (1984), Bergey's manual of systematic bacteriology, Vol. I, Williams and Wilkins, London, pp 141-177.

Lelliot RA, Billing E and Hayward AC (1966), A determinative scheme for the Fluorescent Plant Pathogenic Pseudomonads, J. App. Bacteriol 29: 70-489. 
Lelliot RA and Dickey RS (1984), Genus VII. Erwinia Winslow, Broadhurst, Buchanan, Krumwiede, Rogers and Smith 1920, 209 ${ }_{\mathrm{AL}}$ In: Bergey's Manual of Systematic Bacteriology, Vol. 1, Eds. Krieg NR and Holt JG, Williams \& Wilkins Co, Baltimore, pp 469-476.

Mortensen CN (1997), Seed Bacteriology laboratory guide, Danish Govt. Ins. Seed Pathol (DGISP) for developing countries, Copenhagen, Denmark, pp 1-2.

Nabhan S, Al-Chaabi S and Abu-Ghorrah M (2006), Evaluation of pathogenicity of different Erwinia isolates causal agents of potato soft rot and blackleg, and assessment of susceptibility of some potato cultivars under laboratory conditions, $9^{\text {th }}$ Arab Congress of Plant Protection, 19-23 November 2006, Damascus, Syria.

Perombelon MCM and Kelman A (1980), Ecology of soft rot Erwinias, Ann. Rev. Phytopathol 18: 361-387.

Rasul MG, Islam MA and Sheikh MHR (1999), Storability of different potato varieties under natural conditions, Bangladesh J. Sci. and Indust. Res. 34(1): 86-90.

Rich EE (1983), Potato Diseases, Academic Press, New York, London.

Schaad NW (1988), Laboratory guide for identification of plant pathogenic bacteria, Bacteriol. Commit. Amr. Phytopath. Soc. Minesota.

Seo ST, Furuya N, Lim CK, Tsuchiya K and Takanami Y (2001), Variation of Erwinia carotovora subsp. carotovora isolated from Korea, J. Fac. Agril. Kyushu Univ. 45: 431-436.

Sherf AF and Macnab AA (1986), Vegetable diseases and their control, $2^{\text {nd }}$ Ed., A Wiley Interscience Publication, John Wiley and Sons, Inc. New York.
Shing RS (1985), Diseases of Vegetable crops, Oxford and IBA Publishing Company Pvt. Ltd., New Delhi, p 331.

Shing RS (2001), Plant Disease, Oxford and IBA Publishing Company Pvt. Ltd., New Delhi, p 86-90.

Smith C and Bartz JA (1990), Variation in the pathogenicity and aggressiveness of isolates of Erwinia carotovora subsp. carotovora isolated from different hosts, Plant Dis. 74: 505-509.

Suslow TV, Schroth MN and Isaka M (1982), Application of a rapid method for Gram differentiation of plant pathogenic and saprophytic bacteria without staining, Phytopathol 72: 917-98.

Thornley MJ (1960), The differentiation of $P$. solanacearum from other gram-negative bacteria on the basis of agrinine metabolism, J. App. Bacteriol 23: 37-52.

Togashi J.(198), Identification of the organisms causing the soft rot disease in vegetables in the fields of Tsuruaka district, Bull. Yamaga Univ. Agr. Sci. 10(3): 473-478.

Toth IK, Kenneth SB, Maria CH and Paul RJB (2002), Soft rot erwiniae: from genes to genomes, Mol. Plant Pathol 4(1): 17-30.

Yi YK and Park YM (1999), Soft rot of onion stored under low temperature condition caused by Erwinia rhapontici and Burkholderia cepacia, J. Agril. Sci. Tech. (Andong Univ) 6:33-40.

Received: 07 November 2016; Revised: 15 December 2016; Accepted: 28 December 2016. 